\title{
The ATP- and tolbutamide-sensitivity of the ATP-sensitive K-channel from human pancreatic $B$ cells
}

\author{
F.M.Ashcroft ${ }^{1}$, M.Kakei ${ }^{1}$, J.S.Gibson ${ }^{1}$, D.W.Gray ${ }^{2}$ and R.Sutton ${ }^{2}$ \\ ${ }^{1}$ University Laboratory of Physiology, and ${ }^{2}$ Nuffield Department of Surgery, John Radcliffe Hospital, Oxford, UK
}

\begin{abstract}
Summary. The ATP- and sulphonylurea-sensitivity of the ATP-sensitive K-channel was measured in human pancreatic $B$ cells. In inside-out patches, half-maximal inhibition of channel activity was produced by $10 \mu \mathrm{mol} / 1$ ATP (with $2 \mathrm{mM}$ $\mathrm{Mg}^{2+}$ ) and ATP-inhibition was partially antagonised by ADP. A significantly lower sensitivity to ATP was found in whole-cell recordings. Tolbutamide inhibited whole-cell ATPsensitive K-currents half-maximally at $18 \mu \mathrm{mol} / 1$; the sensitivity to tolbutamide was somewhat less in the inside-out patch.
\end{abstract}

Ca-activated K-channels were unaffected by tolbutamide $(10 \mathrm{mmol} / 1)$. These results resemble those found for rodent $B$ cells and suggest that sulphonylureas exert their therapeutic effects in Type 2 (non-insulin dependent) diabetes by inhibition of the ATP-sensitive K-channel.

Key words: ATP-sensitive K-channel, pancreatic B cell, human islet, sulphonylurea, tolbutamide, insulin secretion.
The activity of the ATP-sensitive $\mathrm{K}$-channel is thought to play a central role in the physiological regulation of insulin secretion from the pancreatic B-cell [1, 2]. Studies of rodent B cells and B cell lines have led to the proposal that an increase in the cytosolic ATP/ADP ratio, resulting from glucose metabolism, inhibits channel activity. This produces membrane depolarization and precipitates a chain of events that culminates in insulin secretion.

The channel is also the target for the hypoglycaemic sulphonylureas used clinically in the treatment of Type 2 (non-insulin-dependent) diabetes mellitus. These drugs inhibit channel activity in rodent $B$ cells [3-7] and thereby stimulate electrical activity and insulin release [8]. It has therefore been suggested that a defect in the regulation of the ATP-sensitive K-channel may be involved in the initial pathology of Type 2 diabetes [9].

Information about the properties of this channel in man is scarce. We have shown previously that the normal human B-cell possesses a $\mathrm{K}$-channel inhibited by both ATP and the sulphonylurea, tolbutamide [9]. A similar channel is also found in human insulinoma cells [10]. In this paper we present a detailed analysis of the properties of the ATP-sensitive K-channel of the human B cell. Our results indicate that the rodent B cell constitutes a good model for that of the human and provide support for the idea that the therapeutic action of tolbutamide in man is mediated via inhibition of the ATP-sensitive K-channel.

\section{Materials and methods}

\section{Preparation}

Human pancreata were removed (with permission) from nondiabetic, heart-beating caldaver organ donors and islets of Langerhans isolated under aseptic conditions using a method similar to that described previously [11]. There were 2 male donors aged 27 and 37, and 3 female donors aged 19,55 and 58. In brief, the pancreatic duct was cannulated and the pancreas distended with $2 \mathrm{ml} / \mathrm{g}$ prewarmed collagenase $(6 \mathrm{mg} / \mathrm{ml})$ in Hank's solution. The pancreas was incubated in a water bath at $39^{\circ} \mathrm{C}$ for $25 \mathrm{~min}$ then cooled rapidly in ice cold Hank's containing $20 \mathrm{mmol} / 1$ HEPES and $5 \mathrm{~g} / 1$ bovine serum albumin. The tissue was dispersed by teasing, shaking and gentle syringing, with frequent washing and centrifugation at $50 \mathrm{~g}$ for $10 \mathrm{~s}$ in this last solution. The dispersed tissue was passed through a $500 \mu \mathrm{m}$ filter, packed by centrifugation at $350 \mathrm{~g}$ for $10 \mathrm{~s}$, then underlaid on a multilayered discontinuous Ficoll density gradient of between 1.090 and 1.040. Islets rose to higher levels than exocrine tissue and final islet preparations consisted of between 1,000 and 2,000 islets/g pancreas with purities upwards of $50 \%$. For patch clamp studies, islets were then hand-picked for dissociation into single cells.

This method produced islets that respond to glucose stimulation with dose-dependent increases of glucose oxidation and insulin secretion $[12,13]$. Islet identity was confirmed for each B-cell preparation used in this study by dithizone staining, by insulin release in response to glucose perifusion and by light as well as electron microscopy (data not shown). About $80 \%$ of islet cells in the adult human pancreas are $B$ cells [14]. 
Islets were cultured overnight and then dissociated into single cells by collagenase digestion and mechanical dispersion [15]. Cells were maintained for 1-4 days in RPMI 1640 tissue culture medium supplemented with fetal calf serum $(10 \%)$, penicillin $(100 \mathrm{U} / \mathrm{ml})$ and streptomycin $(0.1 \mathrm{mg} / \mathrm{ml})$ in a humidified atmosphere of $95 \%$ air, $5 \%$ $\mathrm{CO}_{2}$ at $37^{\circ} \mathrm{C}$.

\section{Electrophysiology}

Standard patch clamp methods were used to record whole-cell currents, and single channel currents from inside-out membrane patches [16]. Pipettes were pulled from borosilicate glass (Rochester Scientific, Rochester, NY, USA), coated with Sylgard close to their tips to reduce their electrical capacitance and fire-polished immediately before use. They had resistances of 3-5 Megaohm when filled with $140 \mathrm{mmol} / \mathrm{l}$ $\mathrm{KCl}$. The reference potential for all measurements was the zero current potential of the pipette before establishment of the seal.

Currents were recorded using a LIST EPC7 patch clamp amplifier (List Electronic, Darmstadt, FRG) and stored on FM tape (Racal Recorders, Hythe, UK) for later analysis; the frequency response of the recording system was $2.5 \mathrm{kHz}$ for whole-cell currents and $10 \mathrm{kHz}$ for single channel currents. The resting potential in whole-cell experiments was measured as the potential at which the pipette current was zero.

No series resistance compensation was used in whole-cell experiments and no corrections have been made for liquid junction potentials $(<5 \mathrm{mV})$.

\section{Solutions}

During whole-cell experiments the bath contained extracellular solution (solution $\mathrm{A}$, in mmol/l): $135 \mathrm{NaCl}, 5 \mathrm{KCl}, 5 \mathrm{CaCl}_{2}, 2 \mathrm{MgSO}_{4}$, 5 HEPES (titrated to $\mathrm{pH} 7.4$ with $\mathrm{NaOH}$ ). The pipette was filled with an intracellular solution $\left(\mathrm{B}\right.$, in mmol/l): $107 \mathrm{KCl}, 2 \mathrm{MgSO}_{4}$, $1 \mathrm{CaCl}_{2}, 11$ Ethylene-glycol-bis( $\beta$-aminoethyl Ether) $\mathrm{N}, \mathrm{N}, \mathrm{N}^{\prime}, \mathrm{N}^{\prime},-\mathrm{Te}$ traacetic Acid (EGTA:0.06 $\mu \mathrm{M}$ free $\mathrm{Ca}^{2+}$ ), 11 HEPES (titrated to $\mathrm{pH} 7.2$ with $\mathrm{KOH}$; additional $\mathrm{K}^{+}$about $\left.30 \mathrm{mmol} / 1\right)$. In most experiments, $0.3 \mathrm{mmol} / 1$ ATP (disodium salt) was included in the pipette solution; in rodent B-cells this concentration of ATP blocks ATP-sensitive K-currents only slightly in whole-cell recordings [5] but prevents rundown of channel activity [5] and maintains the sensitivity to tolbutamide [20]. Tolbutamide was dissolved in $\mathrm{NaOH}$ and solutions containing tolbutamide were made fresh each day.

For inside-out patch recordings the pipette was filled with a high $\mathrm{K}^{+}$extracellular solution (solution $\mathrm{C}$ ) in which $\mathrm{KCl}$ replaced $\mathrm{NaCl}$; the bath contained intracellular solution (B) to which adenine nucleotides were added as detailed in the text. The high $\mathrm{Ca}^{2+}$ intracellular solution (solution $\mathrm{D}$ ) was the same as solution $\mathrm{B}$ except that the CaEGTA buffer was adjusted to give $1 \mu \mathrm{M}$ free $\mathrm{Ca}^{2+}$. To maintain activity of ATP-sensitive $\mathbf{K}$-channels in inside-out patches we used a protocol based on that of Ohno-shosaku et al. [19]. Patches were excised into an intracellular solution containing $0.1 \mathrm{mmol} / \mathrm{l}$ $\mathrm{ATP}+0.1 \mathrm{mmol} / \mathrm{l} \mathrm{ADP}+2 \mathrm{mmol} / 1 \mathrm{Mg}^{2+}$, and a $60 \mathrm{~s}$ exposure to this solution was alternated with each test solution. All patches were tested for ATP sensitivity. Test solutions were applied in random order.

In whole-cell experiments the perfusion system allowed the bath solution to be exchanged within $30 \mathrm{~s}$. A micro-superfusion system was used for all excised patch experiments [21]. Experiments were carried out at room temperature $21-23^{\circ} \mathrm{C}$.

\section{Data analysis}

For analysis of single channel recordings, current records were amplified $(\mathrm{x} 10)$ and low pass filtered using an 8-pole Bessel filter (Frequency Devices, Haverhill, Mass, USA) set at less than half the sample frequency ( $-3 \mathrm{db}$ value). They were then digitised using a $12 \mathrm{bit}$ ADC (Indec, Sunneyvale Calif, USA) controlled by a PDP 11/73 computer (Digital Equipment Corporation-Basingstoke, UK). The sample rate was set at $5 \mathrm{kHz}$. Probability density histograms were constructed by forming histograms of all digitised data points and expressing the number in each histogram bin as a fraction of the total number of data points sampled. Dose-response curves for nucleotide or tolbutamide inhibition were constructed by measuring the mean current $(I)$ and expressing this as a fraction of its amplitude in control solution $\left(I_{c}\right)$. $I$ was computed for data lengths of $30 \mathrm{~s}$ by integrating the current record after subtraction of the baseline current. The baseline current (i.e. the current level when all channels are closed) was either measured directly (when channel activity was low) or in the presence of $1 \mathrm{mmol} / 1$ ATP. Dose-response relationships for ATP and tolbutamide inhibition were fitted by the function

$I / I_{\mathrm{c}}=1 /\left(1+\left([\mathrm{X}] / K_{\mathrm{i}}\right)^{\mathrm{n}}\right)$

where $[\mathrm{X}]$ is the concentration of inhibitor, $\mathrm{n}$ is the slope parameter (Hill co-efficient) and $K_{\mathrm{i}}$ is the concentration at which inhibition is half maximal. In the case of whole-cell currents, $I$ refers to the wholecell current measured in the presence of inhibitor and $I_{\mathrm{c}}$ to the mean of that measured before and after the application of the drug. These values represent the average amplitude of several successive current responses which were measured directly from a digital oscilloscope once a stable current level was obtained.

For some figures the records were subsequently replayed onto a Gould 2200 (Gould, Cleveland, Ohio, USA) chart recorder which has a frequency response of $150 \mathrm{~Hz}$.

\section{Statistical analysis}

All data are quoted as mean \pm SEM for $n$ observations.

\section{Results}

\section{Whole-cell currents}

ATP-sensitive K-currents were measured in the wholecell recording configuration using the procedure developed by Trube et al. [5]. The cell was held at $-70 \mathrm{mV}$ and hyperpolarizing and depolarizing pulses of $10 \mathrm{mV}$ amplitude and $100 \mathrm{~ms}$ duration were applied alternately at a rate of $55 \mathrm{~Hz}$. Most of the resulting current flows through ATP-sensitive $\mathrm{K}$-channels since voltage-dependent currents are not activated by these low pulse amplitudes [22] and activation of Ca-dependent $\mathrm{K}$ channels [23] was prevented by buffering the free $\mathrm{Ca}^{2+}$ in the intracellular solution to $0.06 \mu \mathrm{mol} / 1$.

As observed for mouse B cells [5], following establishment of the whole-cell configuration there was a progressive increase in the current elicited by a $10 \mathrm{mV}$ depolarizing pulse, from an initial value of $0.6 \pm 0.3 \mathrm{pA}$ $(n=9)$ to a maximal amplitude of $87 \pm 23 \mathrm{pA}(n=9)$ between 7 and $25 \mathrm{~min}$ later. We presume this increase in conductance results from dialysis of ATP from the cell interior leading to activation of ATP-sensitive K-channels.

The maximal conductance remained relatively stable when the intracellular solution contained $0.3 \mathrm{mmol} / 1$ ATP but in most cases subsequently declined in amplitude if ATP was omitted. This is also the 
A

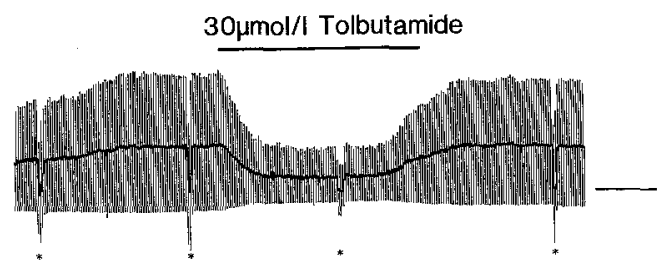

$100 p A\left\lfloor\frac{}{1 \min }\right.$

B

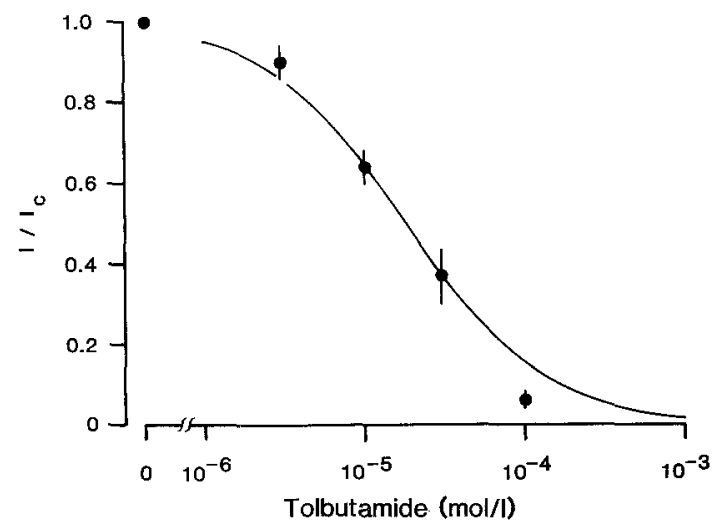

Fig. 1A and B. Effects of tolbutamide on whole-cell K currents. The pipette contained intracellular solution (B) plus $0.3 \mathrm{mmol} / 1$ ATP. A Whole-cell currents (upper trace) and membrane potential (lower trace). The holding potential was $-70 \mathrm{mV}$ and current responses to $\pm 10 \mathrm{mV}$ amplitude pulses appear as vertical lines due to the compressed time scale. The line on the right indicates the zero current level and the asterisks indicate periods at which the holding potential was shifted to the zero current level for measurement of the resting potential. $30 \mu \mathrm{mol} / 1$ tolbutamide was added to the bath for the period indicated by the horizontal line. Chart recorder trace. B Relationship between tolbutamide concentration (logarithmic scale) and the whole-cell current $(I)$ expressed as a fraction of that in the absence of the drug $\left(I_{\mathrm{c}}\right)$. Data points represent the mean \pm SEM for 3-6 cells. The line through the data points is drawn to equation 1 of the text with $n=1$ and $K_{\mathrm{i}}=18 \mu \mathrm{mol} / \mathrm{l}$

case for rodent B cells [5] and probably reflects the rundown of the ATP-sensitive K-channel in nucleotide-free solutions. There did not appear to be a significant block of whole-cell currents by $0.3 \mathrm{mmol} / 1 \mathrm{ATP}$ as the maximum washout currents were $10.4 \pm 3.2 \mathrm{pA} /$ picofarad (pF) $(n=4)$ and $11.1 \pm 1.6 \mathrm{pA} / \mathrm{pF}(n=5)$ for solutions containing $0 \mathrm{mmol} / 1 \mathrm{ATP}$ and $0.3 \mathrm{mmol} / \mathrm{l} \mathrm{ATP}$, respectively.

The average capacitance of the human B cell was $7.6 \pm 1.1 \mathrm{pF}(n=9)$.

\section{Effects of external tolbutamide on whole-cell currents}

Sulphonylureas increase plasma insulin levels in man [24], stimulate insulin release from isolated rodent islets [25] and inhibit the ATP-sensitive K-channels of rodent
B cells [5]. It has therefore been postulated that the ability of these drugs to stimulate insulin release in man results from inhibition of the ATP-sensitive K-channel.

We tested the effect of the sulphonylurea tolbutamide on whole-cell ATP-sensitive K-currents once the washout current had reached a stable amplitude. Tolbutamide reversibly decreased both the current response to a $10 \mathrm{mV}$ voltage pulse and the holding current required to maintain the cell at $-70 \mathrm{mV}$ (Fig. 1 A). High concentrations of the drug $(1 \mathrm{mmol} / 1)$ were not always fully reversible. Tolbutamide inhibition was associated with B cell depolarization, the zero current potential reversibly shifting from -76 to $-69 \mathrm{mV}(n=3)$ in the presence of $1 \mathrm{mmol} / 1$ tolbutamide.

The relationship between tolbutamide concentration and the whole-cell current is shown in Figure 1B. The line through the data points was calculated according to equation 1 (as described in the Methods) using a Hill co-efficient of 1 and taking $K_{\mathrm{i}}$, the concentration required for half-maximal inhibition, as $18 \mu \mathrm{mol} / \mathrm{l}$. This result is similar to those found for rodent $B$ cells, where a Hill co-efficient of 1 and values for $K_{\mathrm{i}}$ of $7 \mu \mathrm{mol} / 1$ [5], $17 \mu \mathrm{mol} / 1[4]$ and $4 \mu \mathrm{mol} / 1$ [7] are reported.

\section{Effects of ATP on single channel currents}

As previously described for rodent $B$ cells and B cell lines [17-19], intracellular ATP has a dual effect on channel activity in the human $B$ cell; it both inhibits the channel and is required to maintain channel activity.

Following excision of an inside-out patch into nucleotide-free solution, channel activity initially increases, indicating that the ATP-sensitive K-channel is subject to resting inhibition in the intact cell, even in glucose-free solution. Subsequently, the channel activity declines again, a process known as rundown. In rodent $\mathrm{B}$ cells, rundown of channel activity can be prevented by intermittent exposure of the patch to phosphorylating solutions containing MgATP [17-19]. To study the inhibitory effect of ATP on channel activity in human B-cells we used a protocol similar to that described by Ohno-shosaku et al. [19], alternating test solutions $(15-20 \mathrm{~s})$ with a $60 \mathrm{~s}$ exposure to a control solution containing $0.1 \mathrm{mmol} / 1 \mathrm{ATP}, 0.1 \mathrm{mmol} / 1 \mathrm{ADP}$ and $2 \mathrm{mmol} / \mathrm{Mg}^{2+}$. To control for any residual rundown, channel activity in the test solution was expressed as a fraction of that in the adjacent control.

\section{Inhibition by $A T P$}

Figure $2 \mathrm{~A}$ illustrates channel activity in control solution (a) and its progressive inhibition by increasing ATP concentrations (b-d). This patch contained more than 10 channels so that individual openings are difficult to resolve at very low ATP concentrations $(1 \mu \mathrm{mol} / 1$, d). Channel activity was reduced to about $50 \%$ in rodent B cells by $10 \mu \mathrm{mol} / 1$ ATP (c) and almost completely inhibited by $100 \mu \mathrm{mol} / 1$ (b). 
A

a

control: $0.1 \mathrm{mmol} / / \mathrm{ATP}, 0.1 \mathrm{mmol} / \mathrm{ADP}$

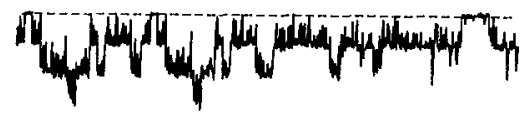

$5 p A L-100 \mathrm{~ms}$

b

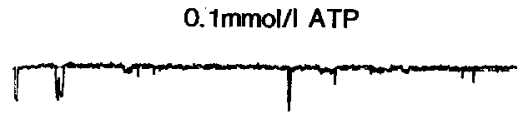

C

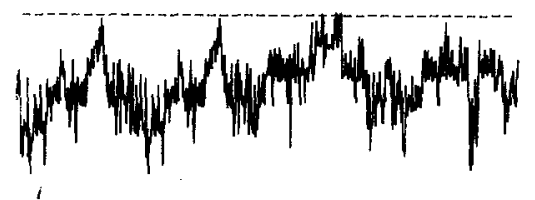

d

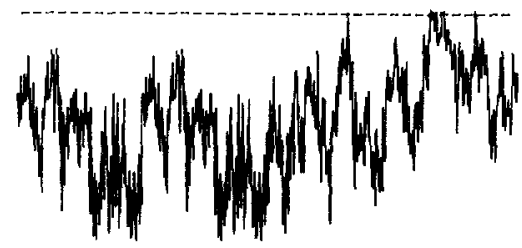

B

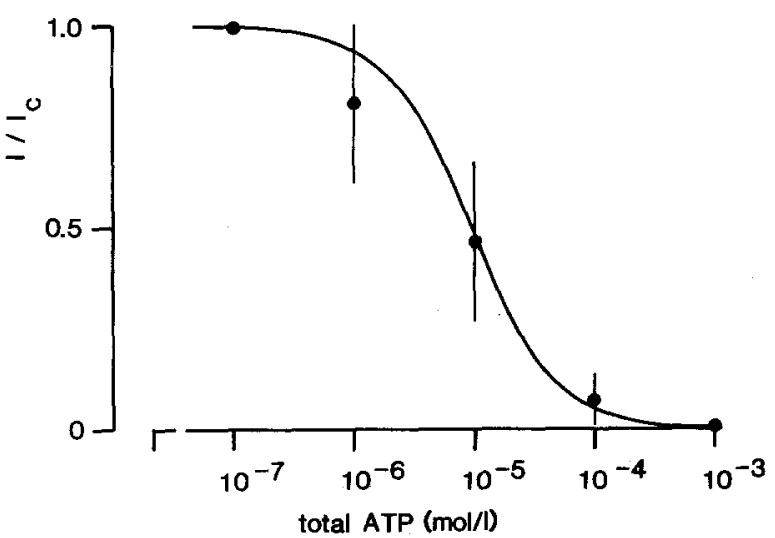

Fig. $2 A$ and B. Inhibition of single channel currents by ATP. A a-d Single channel currents recorded from an inside-out patch at a membrane potential of $-60 \mathrm{mV}$. Pipette $140 \mathrm{mmol} / \mathrm{L} \mathrm{K}$ external solution; Bath, intracellular solution with the addition of adenine nucleotides as indicated. The dashed line indicates the current level when all the channels are closed. All records come from the same patch. Filter, $1 \mathrm{kHz}$; sample rate, $5 \mathrm{kHz}$. B Relationship between intracellular ATP concentration (logarithmic scale) and the mean patch current expressed as a fraction of that in $0.1 \mu \mathrm{mol} / \mathrm{I}$ ATP. Data points represent the mean \pm SEM for 4 patches. Test solutions (b-d) were alternated with a control solution containing $0.1 \mathrm{mmol} / 1 \mathrm{ATP}+0.1 \mathrm{mmol} / 1 \mathrm{ADP}+2 \mathrm{mM} \mathrm{Mg}^{2+}$ (a) as described in the text. The line is drawn to equation 1 of the text with $K_{\mathrm{i}}=9.6 \mu \mathrm{mol} / 1$ and $n=1.2$
The relationship between ATP concentration and channel activity is quantified in Figure $2 \mathrm{~B}$. The mean current in the presence of ATP $(I)$ was expressed as a function of that in the adjacent control solution $\left(I_{c}\right)$, and $I / I_{\mathrm{c}}$ was then normalised to the value measured for $0.1 \mu \mathrm{mol} / 1$ ATP. The line is drawn to equation 1 of the text with a Hill co-efficient of 1.2 and half maximal inhibition at $10 \mu \mathrm{mol} / 1 \mathrm{ATP}$. Both these values are close to those reported for rodent $B$ cells and $B$ cell lines where the Hill co-efficients range from 1.0 to 1.8 and values for $K_{\mathrm{i}}$ from $13 \mu \mathrm{mol} / 1$ to $78 \mu \mathrm{mol} / 1$ total ATP [1].

Comparison of traces $\mathrm{a}$ and $\mathrm{b}$ in Figure $2 \mathrm{~A}$ shows that ADP is able to relieve channel inhibition by ATP, as described for rodent $B$ cells [18, 26, 27]. In 4 cells, the mean current measured in a solution containing $0.1 \mathrm{mmol} / 1 \mathrm{ADP}+0.1 \mathrm{mmol} / 1 \mathrm{ATP}$ was reduced by $80.3 \pm 11 \%$ when ADP was removed.

\section{Effect of internal tolbutamide on single channel currents}

Figure $3 \mathrm{~A}$ illustrates the inhibitory effect of tolbutamide on ATP-sensitive K-currents recorded in an inside-out patch from a human B cell. The probability density functions show that $100 \mu \mathrm{mol} / 1$ tolbutamide does not alter the single channel current amplitude but markedly reduces channel activity. This is in accord with previous observations on rodent B cells [5].

We used the following protocol to construct the dose-response curve for tolbutamide in the inside-out patch (Fig. 3 B). The patch was exposed to the sequence: $60 \mathrm{~s}$ control solution (intracellular solution containing $0.1 \mathrm{mmol} / 1$ ATP, $0.1 \mathrm{mmol} / 1$ ADP, $2 \mathrm{mmol} / 1 \mathrm{Mg}^{2+}$ ), $15 \mathrm{~s}$ nucleotide-free intracellular solution, then to nucleotide-free solution containing tolbutamide (15 s) and finally to nucleotide-free solution again. This sequence was then repeated with a different tolbutamide concentration. The mean current in the presence of the drug $(I)$ was then plotted as a function of the average of the mean current recorded in nucleotide-free solution before and after drug application $\left(I_{\mathrm{c}}\right)$.

It is clear that the channel is far less sensitive to tolbutamide applied to the internal membrane surface than when the drug is applied externally to an intact cell: in the inside-out patch configuration more than $100 \mu \mathrm{mol} / 1$ tolbutamide was required for $50 \%$ inhibition (compare $18 \mu \mathrm{mol} / 1$, Fig. 1B). In one experiment in which tolbutamide was tested in the presence of $0.1 \mathrm{mmol} / 1$ ATP and $0.1 \mathrm{mmol} / 1 \mathrm{ADP}$, however, the tolbutamide sensitivity more closely approximated that of the whole-cell recordings (data not shown).

\section{Ca-activated K-channel}

In addition to ATP-sensitive K-currents we also observed a Ca-activated $\mathrm{K}$-channel in patches excised from human B cells (Fig.4). This channel was studied in 
A
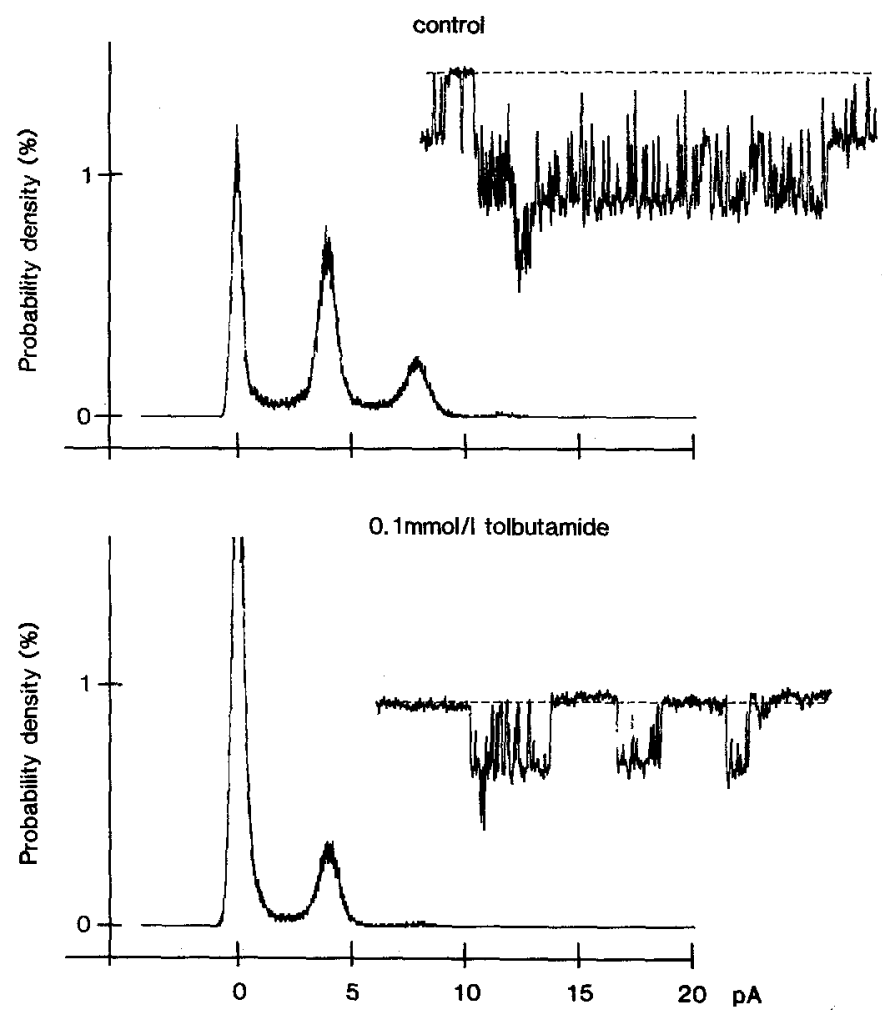

B

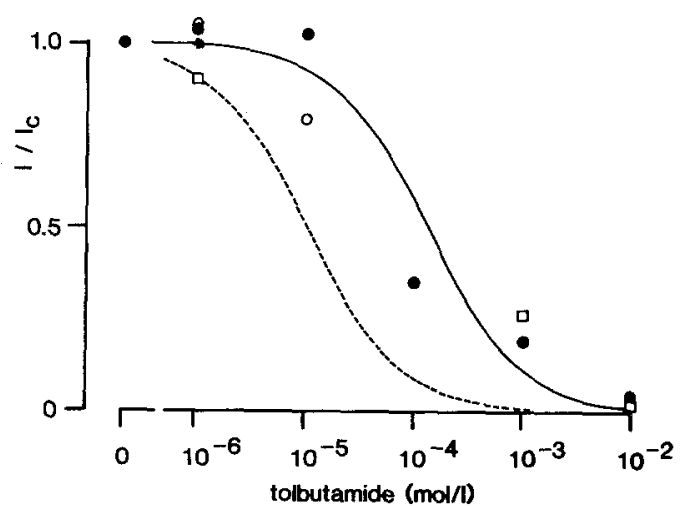

Fig.3 A and B. Inhibition of single channel currents by tolbutamide. A Probability density histograms and single channel currents (inset) recorded at $-60 \mathrm{mV}$ from an inside-out patch before (above) and after (below) the addition of $100 \mu \mathrm{mol} / \mathrm{l}$ tolbutamide to the bath solution. Bath, intracellular solution (no nucleotides). Pipette, $140 \mathrm{mmol} / 1$ $\mathrm{K}$ external solution. The dashed line indicates the current level when all channels are closed. Sample rate, $5 \mathrm{kHz}$; filter, $1 \mathrm{kHz}$. B Relationship between tolbutamide concentration (logarithmic scale) and mean current, expressed as a fraction of that in the absence of tolbutamide. Symbols refer to different patches. The solid line is drawn to equation 1 with $n=1$ and $K_{\mathrm{i}}=130 \mu \mathrm{mol} / 1$. The dashed line is the same as that drawn in Figure $1 \mathrm{~B}\left(K_{\mathrm{i}}=18 \mu \mathrm{mol} / \mathrm{l}\right)$

nucleotide-free solution after the rundown of ATP-sensitive K-currents. Figure $4 \mathrm{~A}$ shows a typical recording of channel activity at $-60 \mathrm{mV}$ in an intracellular solution containing $10^{-6} \mathrm{~mol} / 1 \mathrm{Ca}^{2+}$ and that this activity is
A

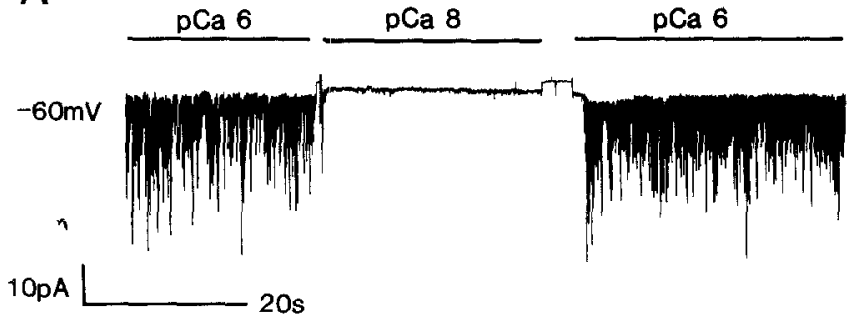

B
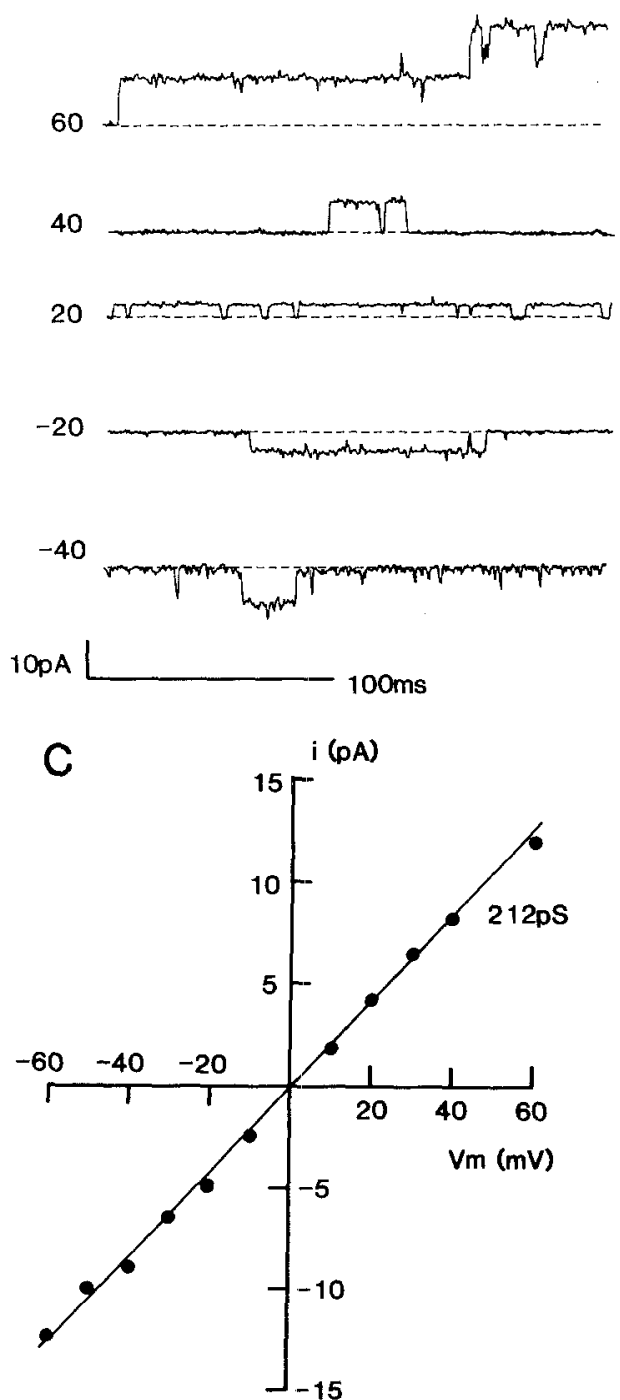

Fig.4 A-C. Ca-activated K-channel. A Single channel currents recorded at $-60 \mathrm{mV}$ in solution lacking adenine nucleotides at the free $\mathrm{Ca}^{2+}$ concentrations indicated. Pipette, $140 \mathrm{mmol} / 1 \mathrm{~K}$ external solution. The upward deflections on the current trace are artefacts associated with the solution exchange [21]. Chart recorder traces. B Single channel currents recorded at the potentials indicated to the left of each trace at a free $\mathrm{Ca}^{2+}$ of $1 \mu \mathrm{M}$. Sample rate, $5 \mathrm{kHz}$; filter $1 \mathrm{kHz}$. The dashed line indicates the current level when the channels are closed. C Current $(i)$-voltage $(V)$ relation for the channel illustrated in $\mathbf{B}$. The line has a slope of $212 \mathrm{pS}$

reversibly abolished when intracellular $\mathrm{Ca}^{2+}$ is reduced to $10^{-8} \mathrm{~mol} / \mathrm{l}$. The open probability is also voltage-dependent, being increased by depolarisation (Fig. 5). Single channel currents recorded at different membrane 


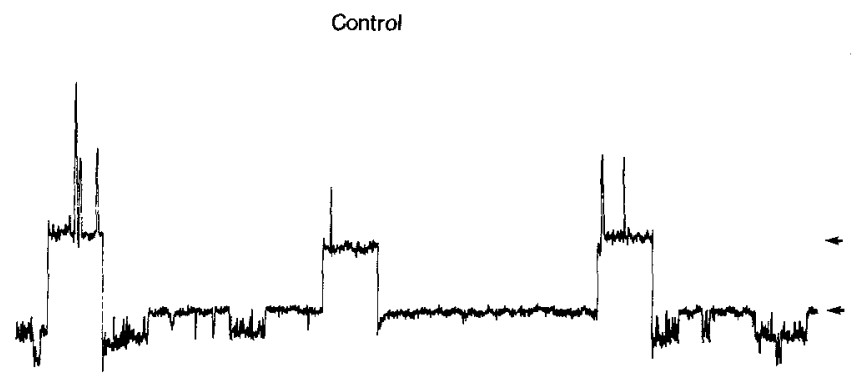

10mmol/l Tolbutamide

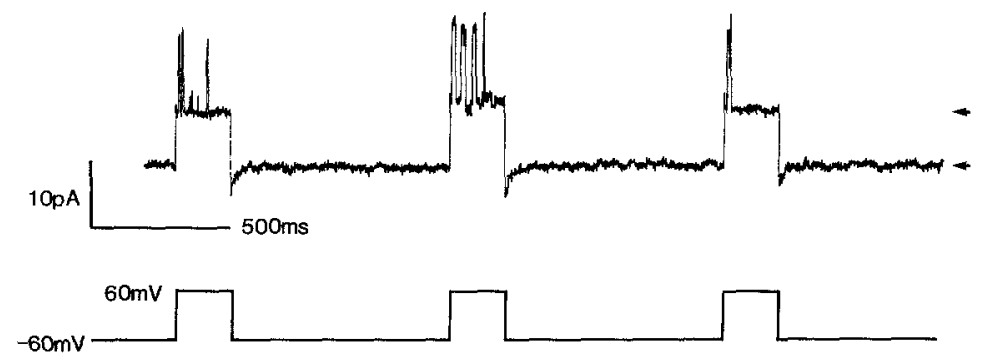

Fig.5. Specificity of tolbutamide. Single channel currents recorded from an inside-out patch in response to pulses from $-60 \mathrm{mV}$ to $+60 \mathrm{mV}$ before (upper trace) and after (below) addition of $10 \mathrm{mmol} / 1$ tolbutamide to the bath solution. The pulse protocol is displayed schematically below the current records. The intracellular solution contained $0.06 \mu \mathrm{mol} / 1$ free $\mathrm{Ca}^{2+}, 0.1 \mathrm{mmol} / 1 \mathrm{ATP}$ and $0.1 \mathrm{mmol} / 1 \mathrm{ADP}$. The arrows to the right of the trace indicate the closed channel level at each potential potentials are illustrated in Figure 4B and the corresponding current-voltage (i-V) relation in C. As expected for a K-selective channel exposed to roughly symmetrical K-concentrations, single channel currents reverse at $0 \mathrm{mV}$. The single $\mathrm{i}-\mathrm{V}$ relation was linear with a slope conductance of 212 pico Siemens (pS), close to that found for the Ca-activated $\mathrm{K}$-channel in rodent $\mathrm{B}$ cells under similar conditions (250 pS; [23]).

\section{Specificity of tolbutamide action}

The Ca-activated $\mathrm{K}$-channel of the rodent $\mathrm{B}$ cell is insensitive to high concentrations of tolbutamide [5], suggesting that inhibition of this channel is not involved in the therapeutic action of the drug. This is also the case for the human B cell. Figure 5 shows that tolbutamide selectively blocks ATP-sensitive K-currents without affecting Ca-activated K-currents in the same patch. The membrane was stepped alternately from $-60 \mathrm{mV}$ to $+60 \mathrm{mV}$ as shown in the lowest trace. At $-60 \mathrm{mV}$, Ca-activated K-channels are not open (free $\mathrm{Ca}^{2+}<0.1 \mu \mathrm{mol} / 1$ ) and only ATP-sensitive K-channels are active. These openings are inward. $\mathrm{Ca}$-activated $\mathrm{K}$ channels open in response to depolarization to $+60 \mathrm{mV}$ and openings are outward as the driving force for $\mathrm{K}^{+}$is now reversed. Figure 5 shows that even $10 \mathrm{mmol} / \mathrm{l}$ tolbutamide was without effect on Ca-activated $\mathrm{K}$-currents whilst abolishing ATP-sensitive $\mathrm{K}^{+}$ channels.

\section{Discussion}

A rough estimate of the number of ATP-sensitive Kchannels per human $\mathrm{B}$ cell can be obtained by combin- ing the results of the whole-cell and single channel experiments. The maximum wash-out conductance in whole-cell recordings was approximately $10 \mathrm{nS}$. If we presume the single channel conductance to be about $20 \mathrm{pS}$ in normal extracellular $\mathrm{K}^{+}$, as it is in rodent $B$ cells $[5,28]$, we obtain 500 ATP-sensitive $\mathrm{K}$-channels per $B$ cell. This must be considered a lower estimate: the actual number of channels will be undoubtably be higher since it is likely that the channel open probability is much less than one.

The ATP-sensitivity of the channel from human $B$ cells measured in the inside-out patch resembles that of the rodent, with a $K_{\mathrm{i}}$ for total ATP of around $10 \mu \mathrm{mol} / 1$. Although more than $95 \%$ of channel activity was inhibited by $0.3 \mathrm{mmol} / 1$ ATP in inside-out patches, in whole-cell recordings this concentration of ATP had no significant blocking effect. A similar discrepancy in ATP-sensitivity between inside-out patches and wholecell recordings has also been reported for rodent $\mathrm{B}$ cells [5] and for cardiac muscle [29, 30]. It seems possible that the difference may be partly due to hydrolysis of ATP to ADP in the whole-cell configuration, which would result in a decrease in the ATP/ADP ratio.

Like the rodent $B$ cell, $[18,26,27]$, the blocking effect of ATP in man is partly antagonised by ADP. Indeed, channel activity in the presence of $100 \mu \mathrm{mol} / \mathrm{I}$ ATP is increased roughly 5 -fold by the addition of a similar concentration of ADP. This suggests that the ATP/ADP ratio is a more important regulator of channel activity than ATP.

The percentage of ATP-sensitive K-channels activated under physiological conditions in the intact human B cell is very low. In whole-cell recordings the input conductance increased approximately 200 -fold from an initial value of less than $50 \mathrm{pS}$ to around $10 \mathrm{nS}$. 
This implies that less than $0.5 \%$ of channels are activated in the intact cell under physiological conditions. The ATP concentration corresponding to this amount of channel activity is $0.1 \mathrm{mmol} / \mathrm{l}$ (Fig. 2). The increase in channel activity seen on patch excision is also consistent with significant channel inhibition in the unstimulated B cell.

Tolbutamide inhibited whole-cell washout currents half maximally at $18 \mu \mathrm{mol} / \mathrm{l}$ (Fig. $3 \mathrm{~B}$ ), a value close to that found in rodent B-cells $(7 \mu \mathrm{mol} / 1,[5] ; 17 \mu \mathrm{mol} / 1$, [4]; $4 \mu \mathrm{mol} / 1,[7])$. This concentration is well within the range of therapeutic plasma levels of free tolbutamide [24]. The tolbutamide sensitivity of the ATP-sensitive Kchannel in human B cells supports previous suggestions that the therapeutic action of sulphonylureas is mediated through inhibition of this channel.

Tolbutamide was considerably less effective in inhibiting channel activity in inside-out patches. Since the drug is lipid soluble it seems unlikely that access to the site of action accounts for this discrepancy; rather we believe it may result from a difference in the intracellular solutions used for the two recording configurations. Several studies of rodent B cells have shown that ATP does not affect the sensitivity of the channel to tolbutamide $[4,6,7]$ so a direct effect of the $0.3 \mathrm{mmol} / 1$ ATP included in the intracellular solution used in whole-cell recordings is not indicated. Instead, it seems probable that the discrepancy is related to the lack of intracellular ADP in excised patch recordings, since Zunckler et al. [20] have shown that cytosolic ADP enhances the channel sensitivity to tolbutamide. Consistent with this hypothesis was the observation that tolbutamide was more effective in one experiment in which the intracellular solution contained $0.1 \mathrm{mmol} / \mathrm{l} \mathrm{ADP}+0.1 \mathrm{mmol} / 1$ ATP. Although in whole-cell recordings, ADP was not included in the pipette solution, it will be formed from hydrolysis of the ATP.

There is good evidence that Type 2 diabetes is associated with disorders in the secretory function of the $B$ cell which result in the failure of glucose to stimulate insulin release [31]. Although we recognise that Type 2 diabetes has a multiple aetiology, the ability of sulphonylureas to stimulate release in Type 2 diabetic patients suggests that events subsequent to closing of the ATPsensitive K-channels remain intact [9]. This raises the possibility that in sulphonylurea-sensitive patients the defect in the B cell may be localised to either (1) glucose uptake (2) glucose metabolism or (3) a defect in the channel which alters its ability to respond to glucose metabolism. Clearly, studies on B cells isolated from diabetic donors are required to distinguish between these possibilities. In the absence of such studies it is worth noting that an increase in futile cycles of glucose metabolism causing ATP hydrolysis has been reported for both liver cells [32] and B cells [33] isolated from Type 2 diabetic patients. Furthermore, in fetal B cells, which also manifest an impaired response to glucose, the ATP- and tolbutamide-sensitivity of the ATP-sensi- tive $\mathrm{K}$-channel is similar to that of the adult but the sugar both fails to increase the ATP content or inhibit the channel [34]. These findings lead us to speculate that one of the causes of Type 2 diabetes may be a disturbance of glucose metabolism which results in defective regulation of ATP-sensitive $\mathrm{K}$-channels and thus failure of insulin release.

Finally, we emphasise that we have not yet observed any marked differences in the properties of the human $B$ cell and those of rodent B cells. The sensitivity to tolbutamide is essentially the same; similarly, the ATP sensitivity and its modulation by ADP resemble those of the rodent. Our studies therefore indicate that the rodent $\mathrm{B}$ cell provides a good model for that of the human.

Acknowledgements. We are grateful to Drs. S.J.H.Ashcroft (Oxford, UK), P. Rorsman (Gothenburg, Sweden) and G. Trube (Basle, Switzerland) for their comments on the manuscript. We thank the British Diabetic Association, the Nordisk UK Fund and the Wellcome Trust for support. F.M.Ashcroft is a Royal Society 1983 University Research Fellow.

\section{References}

1. Ashcroft FM (1988) Adenosine-5'-triphosphate-sensitive $\mathrm{K}^{+}$ channels. Ann Rev Neurosci 11: 97-118

2. Petersen OH, Findlay I (1987) Electrophysiology of the pancreas. Physiol Rev 67: 1054-1116

3. Sturgess NC, Ashford MLJ, Cook DL, Hales CN (1985) The sulphonylurea receptor may be an ATP-sensitive potassium channel. Lancet 8453: 474-475

4. Sturgess NC, Kozlowski RZ, Carrington CA, Hales CN, Ashford MLJ (1988) Effects of sulphonylureas and diazoxide on insulin secretion and nucleotide-sensitive channels in an insulin-secreting cell line. Br J Pharmacol 95: 83-94

5. Trube G, Rorsman P, Ohno-shoskau T (1986) Opposite effects of tolbutamide and diazoxide on the ATP-dependent $\mathrm{K}^{+}$channel in mouse pancreatic B-cells. Pflugers Arch 407: 493-499

6. Dunne MJ, Ilott MC, Petersen OH (1987) Interactions of diazoxide, tolbutamide and $\mathrm{ATP}^{4-}$ on nucleotide-dependent $\mathrm{K}^{+}$ channels in an insulin-secreting cell-line. J Memb Biol 99: 215-224

7. Zunckler BJ, Lenzen S, Manner K, Panten U, Trube G (1988) Concentration-dependent effects of tolbutamide, meglitinide, glipizide, glibenclamide and diazoxide on ATP-regulated $\mathrm{K}$ currents in pancreatic B-cells. Naunyn-Schmiedbergs Arch Pharmacol 337: 225-230

8. Henquin JC, Meissner HP (1982) Opposite effects of tolbutamide and diazoxide on ${ }^{86} \mathrm{Rb}$ fluxes and membrane potential in pancreatic B-cells. Biochem Pharmacol 31: 1047-1415

9. Ashcroft FM, Kakei M, Kelly RP, Sutton R (1987) ATP-sensitive $\mathrm{K}$-channels in isolated human pancreatic $\beta$-cells. FEBS Letts 215 : 9-12

10. Sturgess NC, Carrington CA, Hales CN, Ashford MLJ (1987) Nucleotide-sensitive ion channels in human insulin producing tumor cells. Pflugers Arch 410: 169-172

11. Gray DWR, McShane P, Grant A, Morris PJ (1984) A method for isolation of islets of Langerhans from the human pancreas. Diabetes 33: 1055-1061

12. Grant AM, Christie MR, Ashcroft SJH (1980) Insulin release from human pancreatic islets in vitro. Diabetologia 19: 114-117

13. Harrison DE, Christie MR, Gray DWR (1985) Properties of isolated human islets of Langerhans: insulin secretion, glucose oxidation and protein phosphorylation. Diabetologia 28:99-103 
14. Malaisse-Lagae F, Stefan Y, Cox J, Perrelet A, Orci L (1979) Identification of a lobe in the adult human pancreas rich in pancreatic polypeptide. Diabetologia 17: 361-365

15. Ashcroft FM, Ashcroft SJH, Harrison DE (1987) Effects of 2ketoisocaproate on insulin release and single potassium channel activity in dispersed rat pancreatic $\beta$-cells. J Physiol 385: 517-529

16. Hamill OP, Marty A, Neher E, Sakmann B, Sigworth FJ (1981) Improved patch clamp techniques for high resolution current recordings from cells and cell-free membrane patches. Pflugers Arch 391: $85-100$

17. Findlay I, Dunne MJ (1986) ATP maintains ATP-inhibited $\mathrm{K}^{+}$ channels in an operational state. Pflugers Arch 407:238-240

18. Misler S, Falke LC, Gillis K, McDaniel ML (1986) A metabolite regulated potassium channel in rat pancreatic B cells. Proc Natl Acad Sci USA 83: 7119-7123

19. Ohno-shosaku T, Zunckler BJ, Trube G (1987) Dual effects of ATP on $\mathrm{K}^{+}$currents of mouse pancreatic $\beta$-cells. Pflugers Arch 408: $133-138$

20. Zunckler BJ, Lins S, Ohno-shosaku T, Trube G, Panten U (1988) Cytosolic ADP enhances the sensitivity to tolbutamide of ATP-dependent $\mathrm{K}^{+}$channels from pancreatic $\beta$-cells. FEBS Letts 239: 241-244

21. Kakei M, Ashcroft FM (1986) A microflow superfusion system for use with excised membrane patches. Pflugers Arch 409: 337-341

22. Rorsman P, Trube $G$ (1986) Calcium and delayed potassium currents in mouse pancreatic $\beta$-cells under voltage clamp conditions. J Physiol 374: 531-550

23. Findlay I, Dunne MJ, Petersen $\mathrm{OH}(1985)$ High conductance $\mathrm{K}^{+}$ channel in pancreatic islet cells can be activated and inactivated by internal calcium. J Memb Biol 83:169-175

24. Balant L (1981) Clinical pharmokinetics of sulphonylurea hypoglycaemic drugs. Clin Pharmocokinet 6: 215-241

25. Hermans MP, Schmeer W, Henquin JC (1977) The permissive effect of glucose, tolbutamide and high $\mathrm{K}^{+}$on arginine stimulation of insulin release in isolated mouse islets. Diabetologia 30: 659-665

26. Kakei M, Kelly RP, Ashcroft SJH, Ashcroft FM (1986) The ATPsensitivity of $\mathrm{K}^{+}$channels in rat pancreatic B-cells is modulated by ADP. FEBS Letts 208: 63-66

27. Dunne MJ, Petersen OH (1986) Intracellular ADP activates $\mathrm{K}^{+}$ channels that are inhibited by ADP in an insulin-secreting cell line. FEBS Letts 208: 59-63
28. Ashcroft FM, Kakei M, Kelly RP (1989) Rubidium and sodium permeability of the ATP-sensitive $\mathrm{K}^{+}$channels in single rat pancreatic $\beta$-cells. J Physiol 408: 413-430

29. Kakei M, Noma A, Shibasaki T (1985) Properties of adenosine triphosphate regulated potassium channels in guinea-pig ventricular cells. J Physiol 363: 441-462

30. Noma A, Shibasaki T (1985) Membrane current through adenosine-triphosphate-regulated potassium channels in guinea-pig ventricular cells. J Physiol 363: 463-481

31. Vague $P$, Moulin JP (1982) The defective glucose sensitivity of the $B$ cell in non-insulin dependent diabetes. Improvement after twenty hours of normoglycaemia. Metabolism 31: 139-144

32. Efendic S, Wajngot $\AA$, Vranie $M$ (1985) Increased activity of the glucose cycle in liver. Early charácteristic of type 2 diabetes. Proc Natl Acad Sci USA 82: 2965-2969

33. Rorsman P, Berggren PO, Bokvist K, Efendic S, Khan A, Low H, Welsh M (1988) Doès type II diabetes result from defective regulation of glucose- and ATP-sensitive K-channels? Biosci Abstr 1: 149

34. Rorsman $P$, Bokvist K, Arkhammar $\mathrm{P}$, Berggren PO, Hellerström C, Nilsson T, Welsh $M$, Welsh N (1988) Defective regulation of glucose- and ATP-regulated $K$ channels results in disturbed glucose sensitivity in fetal B cells. Diabetologia 31:537 A

35. Misler S, Gee WM, Gillis KD, Scharp DW, Falke LC (1989) Metabolite-regulated ATP-sensitive $\mathrm{K}^{+}$channel in human pancreatic islet cells. Diabetes 38: 422-427

Received: 27 December 1988

and in revised form: 27 April 1989

Dr. F.M.Ashcroft

University Laboratory of Physiology

Parks Rd

Oxford OX1 3PT

UK

Note added in proof

Since this manuscript was submitted another study concerned with ATP-sensitive $\mathrm{K}$-channels in human B cells has been published [35]. 